Article

\title{
Glyphosate-Resistant Goosegrass from Mississippi
}

\section{William T. Molin *, Alice A. Wright and Vijay K. Nandula}

Crop Production Systems Research Unit, USDA-ARS, 141 Experiment Station Road, Stoneville, MS 38776, USA; E-Mails: ali.wright@ars.usda.gov (A.W.); vijay.nandula@ars.usda.gov (V.N.)

* Author to whom correspondence should be addressed; E-Mail: william.molin@ars.usda.gov; Tel.: +1-662-686-5245; Fax: +1-662-686-5422.

Received: 6 May 2013; in revised form: 17 May 2013 / Accepted: 17 May 2013 /

Published: 29 May 2013

\begin{abstract}
A suspected glyphosate-resistant goosegrass [Eleusine indica (L.) Gaertn.] population, found in Washington County, Mississippi, was studied to determine the level of resistance and whether the resistance was due to a point mutation, as was previously identified in a Malaysian population. Whole plant dose response assays indicated a two- to four-fold increase in resistance to glyphosate. Leaf disc bioassays based on a glyphosate-dependent increase in shikimate levels indicated a five- to eight-fold increase in resistance. Sequence comparisons of messenger RNA for epsps, the gene encoding the enzyme 5-enolpyruvylshikimate-3-phosphate synthase, from resistant and sensitive goosegrass, revealed a cytosine to thymine nucleotide change at position 319 in the resistant accessions. This single nucleotide polymorphism causes a proline to serine amino acid substitution at position 106 in 5-enolpyruvylshikimate-3-phosphate synthase. A real-time polymerase chain reaction assay using DNA probes specific for the nucleotide change at position 319 was developed to detect this polymorphism. Goosegrass from 42 locations were screened, and the results indicated that glyphosate-resistant goosegrass remained localized to where it was discovered. Pendimethalin, $s$-metolachlor, clethodim, paraquat and fluazifop controlled resistant goosegrass $93 \%$ to $100 \%$, indicating that several control options for glyphosate-resistant goosegrass are available.
\end{abstract}

Keywords: glyphosate resistance; point mutation; single nucleotide polymorphism; Eleusine indica 


\section{Introduction}

Resistance to glyphosate, the world's most widely used herbicide [1], was first documented in rigid ryegrass in 1996 [2]. The creation of glyphosate-resistant crops, which dramatically expanded glyphosate-treated acres in recent years, has resulted in increases in the number of weeds evolving resistance [2]. Glyphosate-resistant goosegrass was first documented in Malaysia [3], where resistance to glyphosate was eight- to 12 -fold greater than sensitive plants. Since then, glyphosate-resistant goosegrass has been reported in Taiwan [4], the Philippines [5], Columbia [4] and Tennessee [6]. In Malaysian goosegrass, resistance was caused by a single nucleotide polymorphism (SNP) in epsps, the gene encoding 5-enolpyruvylshikimate-3-phosphate synthase (EPSPS), and was identified as a cytosine to thymine nucleotide change at position 319 of the messenger RNA [7]. This mutation resulted in a proline to serine amino acid substitution at position 106 (P106S) [7]. Another resistant Malaysian goosegrass was shown to have a P106T (threonine) mutation, which conferred a level of resistance similar to the P106S change $[8,9]$. These mutations decrease the binding efficiency of glyphosate to the active site of EPSPS.

In 2009, a goosegrass population, suspected of being resistant to glyphosate, was found at the edge of a soybean field in Washington County, Mississippi. The goosegrass population was not controlled by repeated applications of glyphosate at $0.84 \mathrm{~kg}$ acid equivalent (ae) ha ${ }^{-1}$. The level of resistance has not been characterized for this goosegrass population, and it was unknown if these plants had the same SNPs as are found in resistant Malaysian goosegrass. The objectives of this study were to: quantify the levels of glyphosate resistance in goosegrass; determine whether shikimate accumulation bioassays could differentiate between resistant and sensitive goosegrass; sequence epsps to identify possible nucleotide differences between resistant and sensitive goosegrass; and determine if this glyphosate resistant goosegrass is cross-resistant to other commonly used herbicides. If resistance in Mississippi goosegrass was due to a mutation in the target site, then a SNP assay could be developed to distinguish between resistant and sensitive genotypes.

\section{Results and Discussion}

For the initial studies, three resistant goosegrass accessions, GG14, GG16 and GG19, and one sensitive accession, GG15, were used to assess the glyphosate resistance mechanism. There were no significant differences between experimental runs for whole plant and shikimate determinations, so data were combined. Goosegrass accessions GG14, GG16 and GG19 were more resistant to glyphosate compared to GG15, based on reduction in dry weight (Figure 1). 
Figure 1. Dose response of glyphosate rate and dry weight for GG15, GG19, GG16 and GG14.

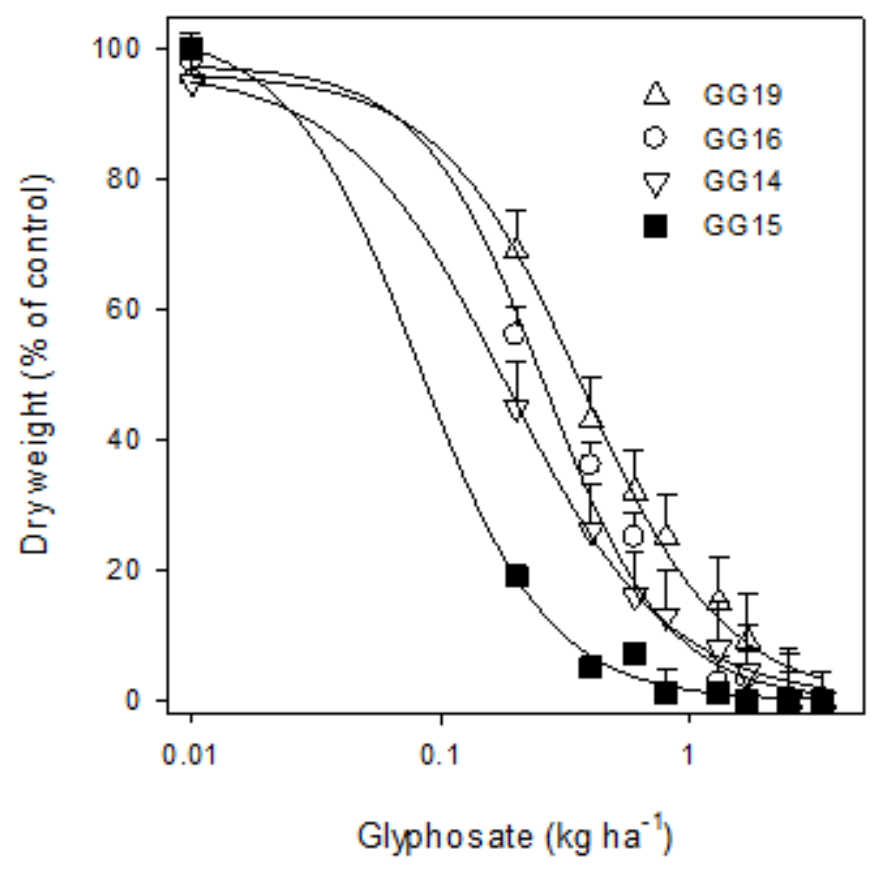

Mean $\mathrm{GR}_{50}$ values (Table 1) were estimated to be $0.08,0.17,0.24$ and $0.35 \mathrm{~kg} \mathrm{ha}^{-1}$ for GG15, GG14, GG16 and GG19, respectively, indicating that GG14, GG16 and GG19 were two to four-fold more resistant to glyphosate than the sensitive GG15.

Table 1. $\mathrm{GR}_{50}$ and resistance factor (R/S ratio) values from dose response of glyphosate rate and dry weight for GG15, GG19, GG16 and GG14 for Figure 1.

\begin{tabular}{ccccc}
\hline Parameters & GG14 & GG15 & GG16 & GG19 \\
\hline Y range & $99.6 \pm 3.9$ & $100.1 \pm 4.2$ & $104.7 \pm 3.7$ & $97.4 \pm 2.6$ \\
Background & $0.4 \pm 6.8$ & $-0.5 \pm 4.4$ & $0.4 \pm 7.3$ & $-5.7 \pm 2.4$ \\
GR $_{50}$ & $0.17 \pm 0.04$ & $0.08 \pm 0.07$ & $0.25 \pm 0.06$ & $0.35 \pm 0.02$ \\
Slope factor & $1.6 \pm 0.32$ & $1.6 \pm 1.24$ & $1.3 \pm 0.22$ & $1.4 \pm 0.2$ \\
R/S & 2 & -- & 3 & 4 \\
\hline
\end{tabular}

Similar increases in goosegrass resistance were previously reported $[3,8,9]$.

The shikimate assay, modified to include four disks per well in $100 \mu \mathrm{L}$ of incubation buffer in a 48 well plate format, resulted in production of sufficient amounts of shikimate for estimation of EPSPS inhibition. GG15 produced about the same levels of shikimate as GG14 and GG19 (Figure 2). 
Figure 2. Dose response of glyphosate rate and shikimate accumulation in leaf disks from GG15 (A), GG14 (B), GG16 (C) and GG19 (D).
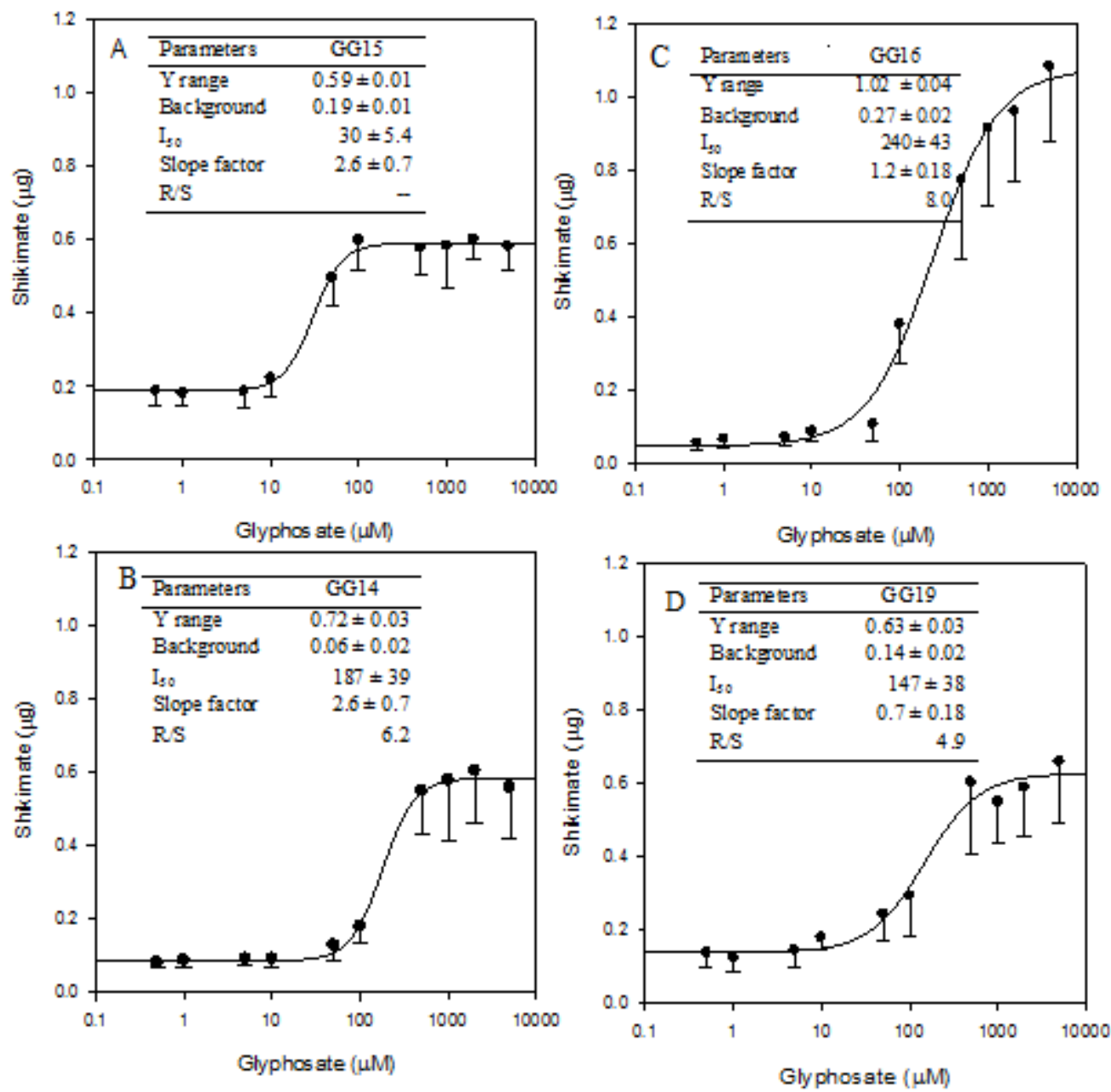

GG16 produced nearly double the amount of shikimate compared to GG14, GG15 and GG19 and continued to produce shikimate at the highest glyphosate concentrations. The inset tables show that the glyphosate concentration resulting in half maximal shikimate production was $30 \mu \mathrm{M}$ for GG15, and estimates for GG14, GG16 and GG19 were 187, 240 and $146 \mu \mathrm{M}$, respectively. These results demonstrate a five- to eight-fold decrease in sensitivity of EPSPS to glyphosate in GG14, GG16 and GG19.

Nucleotide sequences for epsps from GG14, GG15, GG16 and GG19 were assembled and aligned, and sequences flanking the point mutation are shown (Table 2A). Translations of the nucleotide sequences to yield amino acid sequences were also aligned (Table $2 \mathrm{~B}$ ). 
Table 2. Nucleotide alignment (A) of epsps in glyphosate sensitive (accession number AY157642) and resistant (AY157643) Malaysian goosegrass compared with Mississippi GG14 (JN004269), GG15 (JN004268), GG16 and GG19. Corresponding amino acid alignment (B) of 5-enolpyruvylshikimate3-phosphate synthase (EPSPS) in resistant and sensitive goosegrass from Malaysia and Mississippi. Nucleotide and amino acid changes are in bold and underlined. The altered nucleotide and amino acid are at positions 319 and 106 , respectively.

\begin{tabular}{|c|c|}
\hline $\mathbf{A}$ & \\
\hline Origin & Nucleotide residues \\
\hline Consensus Identity & A CTGCAATGCGATCATTGACAGCAGC \\
\hline AY157642 (Malaysia sensitive) & ACTGCAATGCGA $\underline{C} C A T T G A C A G C A G C$ \\
\hline AY157643 (Malaysia resistant) & ACTGCAATGCGATCATTGACAGCAGC \\
\hline GG14 (Mississippi resistant) & ACTGCAATGCGATCATTGACAGCAGC \\
\hline GG15 (Mississippi sensitive) & 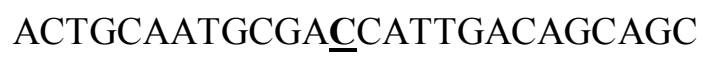 \\
\hline GG16 (Mississippi resistant) & ACTGCAATGCGATCATTGACAGCAGC \\
\hline GG19 (Mississippi resistant) & ACTGCAATGCGATCATTGACAGCAGC \\
\hline \multicolumn{2}{|l|}{ B } \\
\hline Origin & Amino acid residues \\
\hline Consensus Identity & LFLGNAGTAMRSLTAAVTAAGGNATY \\
\hline AY157642 (Malaysia sensitive) & LFLGNAGTAMRPLTAAVTAAGGNATY \\
\hline AY157643 (Malaysia resistant) & LFLGNAGTAMR吕TAAVTAAGGNATY \\
\hline GG14 (Mississippi resistant) & LFLGNAGTAMR吕TAAVTAAGGNATY \\
\hline GG15 (Mississippi sensitive) & LFLGNAGTAMRPLTAAVTAAGGNATY \\
\hline GG16 (Mississippi resistant) & LFLGNAGTAMRLTAAVTAAGGNATY \\
\hline GG19 (Mississippi resistant) & LFLGNAGTAMR느TAAVTAAGGNATY \\
\hline
\end{tabular}

Resistant goosegrass had a C319T change in the nucleotide sequence, which resulted in a predicted change in the amino acid sequence of P106S. Sequences of GG15 and GG14 were reported to GenBank and were assigned accession numbers JN004268 and JN004269, respectively.

The SNP assay for detection of sensitive or resistant alleles was based on a PCR amplification of specific alleles assay [9] and used the TaqMan ${ }^{\circledR}$ Probe Gene Expression Analysis method for analysis. In this assay, there are two primers and two probes. The primers amplify the region containing the SNP of interest and the probes, specific for either the sensitive or the resistant sequence, are distinguished by different fluorescent markers, which are suppressed by a quencher molecule. The probes differ only at the SNP. During amplification, only one of the two probes will bind and release the fluorescent molecule. The T319 probe will only bind to DNA from a resistant plant, and the C319 probe will only bind to DNA from a sensitive plant. The ABI 7500 real-time PCR system can detect different fluorescent molecules within a reaction, allowing for identification of sensitive and resistant individuals. An allelic discrimination plot of goosegrass accessions, from 42 locations at distances from $0.038 \mathrm{~km}$ to $1,680 \mathrm{~km}$ from the point of origin, having either the sensitive (C319) or resistant (T319) alleles of epsps, is shown in Figure 3. 
Figure 3. Allelic discrimination plot of the sensitive (C319) and resistant (T319) alleles of epsps from goosegrass accessions from 42 locations from $0.038 \mathrm{~km}$ to $16,80 \mathrm{~km}$ from the point of origin. DNA from sensitive $(\bullet)$, resistant $(\circ)$ and controls containing no template (口) were amplified in duplicate by the TaqMan ${ }^{\circledR}$ Probe Gene Expression Analysis method. Data were plotted by using the absolute fluorescence of each reporter dye probe.

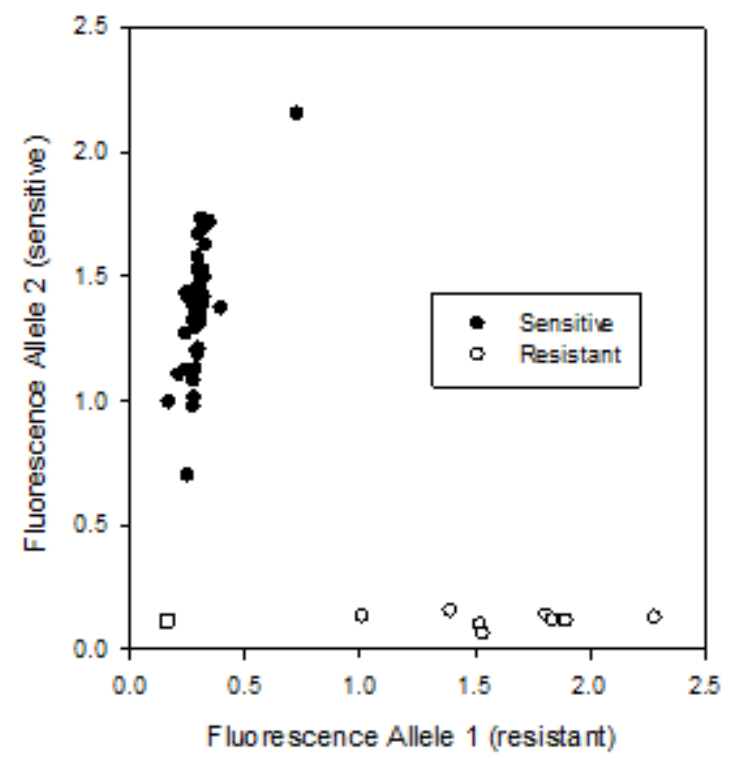

Two clusters representing resistant and sensitive plants were identified. Of the nine resistant plants, three were GG14, GG16 and GG19, and six were plants within $0.1 \mathrm{~km}$ from the point of origin. Heterozygous accessions were not identified, but would have appeared as a third cluster midway between the sensitive and resistant clusters.

Comparison of the mRNA epsps sequences of GG14, GG15, GG16, GG19 and the two Malaysian sequences (AY157642 and AY157643) revealed some sequence variation (Table 3). Aside from the C319T change, only one other nucleotide difference resulted in a change in the amino acid sequence. In GG16, the substitution of a guanine nucleotide for an adenine results in a corresponding amino acid sequence change of threonine to alanine. This change occurs in exon 8 , near the end of the sequence. It is unknown if this change has any effect on the level of resistance in GG16 or the ability of the enzyme to function. In addition to the differences in sequence, three common polymorphisms were also detected (Table 4). These sequence differences were observed in multiple clones within each accession and are most likely due to natural variation among goosegrass populations. The C319T polymorphism responsible for glyphosate resistance may be part of this natural variation that was selected for by repeated applications of glyphosate. 
Table 3. Differences in the mRNA sequence between Mississippi accessions and the Malaysian sensitive accession (AY15762). GG15 epsps mRNA was identical to AY15762.

\begin{tabular}{ccc}
\hline Accession & Nucleotide Change & Amino Acid Change \\
\hline GG14 & $225 \mathrm{~A}$ to $\mathrm{G}$ & None \\
GG14 & $319 \mathrm{C}$ to $\mathrm{T}$ & Proline to serine \\
GG14 & $438 \mathrm{G}$ to $\mathrm{A}$ & None \\
GG14 & $531 \mathrm{C}$ to $\mathrm{T}$ & None \\
GG14 & $651 \mathrm{~A}$ to $\mathrm{G}$ & None \\
GG16 & $225 \mathrm{~A}$ to $\mathrm{G}$ & None \\
GG16 & $319 \mathrm{C}$ to $\mathrm{T}$ & Proline to serine \\
GG16 & $438 \mathrm{G}$ to $\mathrm{A}$ & None \\
GG16 & $651 \mathrm{~A}$ to $\mathrm{G}$ & None \\
GG16 & $1282 \mathrm{~A}$ to $\mathrm{G}$ & Threonine to alanine \\
GG19 & $225 \mathrm{~A}$ to $\mathrm{G}$ & None \\
GG19 & $319 \mathrm{C}$ to $\mathrm{T}$ & Proline to serine \\
GG19 & $438 \mathrm{G}$ to $\mathrm{A}$ & None \\
GG19 & $651 \mathrm{~A}$ to $\mathrm{G}$ & None \\
\hline
\end{tabular}

Table 4. Polymorphisms identified, common to more than one accession. Numbering is based on the Malaysian epsps sequence (AY15762).

\begin{tabular}{ccc}
\hline Polymorphism & Location & Accessions \\
\hline 1543 A to C & Exon 4 & GG14, GG16, GG19 \\
2003 A to T & Intron 4 & GG14, GG16, GG19 \\
2617 T to C & Exon 6 & GG14, GG15 \\
\hline
\end{tabular}

$\mathrm{Ng}$ et al. [9,10] concluded that multiple founding events had occurred in separate locations, rather than spreading of a single resistant allele, since different mutations conferring resistance were spatially separated. Considering that glyphosate-resistant goosegrass populations are widely separated, it is likely that these have also evolved independently. The resistant goosegrass identified in Tennessee [6] is more than two-hundred kilometers from the Mississippi location. Goosegrass collected from surrounding areas and other states did not contain the C319T SNP. It is not known whether the point mutation, which results in the proline to threonine amino acid change at position 106 in EPSPS reported in Malaysia [8,9], was present in Mississippi. This may be due to the limited number of samples sequenced from the location where the resistant plants were found.

The results from the dose response growth experiments, shikimate accumulation bioassays and inferred sequence change in EPSPS based on epsps sequence analysis of resistant accessions indicate that there was an increase in resistance in goosegrass to glyphosate. The SNP conferring resistance to glyphosate in Mississippi goosegrass was identical to that found in resistant goosegrass from Malaysia [7] and in Lolium multiflorum [11]. The levels of resistance in Mississippi goosegrass were similar to those found in other glyphosate-resistant goosegrass populations [5-7,9]. These results indicate that additional herbicide expense and changes to weed management programs may be required to control this goosegrass. Other mechanisms that may contribute to glyphosate resistance in goosegrass, such as gene amplification [12], altered transport [13,14] or vacuolar sequestration [15], have not been studied. 
The efficacy of pendimethalin and metolachlor was $100 \%$ at the lowest rate tested $\left(0.07 \mathrm{~kg} \mathrm{ha}^{-1}\right)$, indicating no cross resistance to these preemergence herbicides (data not shown). The efficacy of the postemergent non-glyphosate mode of action herbicides on resistant and sensitive plants was 95 and 93\% with clethodim, 98 and 98\% with fluazifop-P, 100 and 100\% with paraquat and 80 and $78 \%$ with glufosinate, respectively (Figure 4). These results indicate that although resistance to glyphosate had developed, there are many other herbicides available to slow the spread of this resistance.

Figure 4. Efficacy of selected herbicide treatments applied postemergence to 5-8 $\mathrm{cm}$ tall glyphosate-resistant (R) and -susceptible (S) goosegrass plants three weeks after treatment (WAT). Herbicide rates are described in the text.

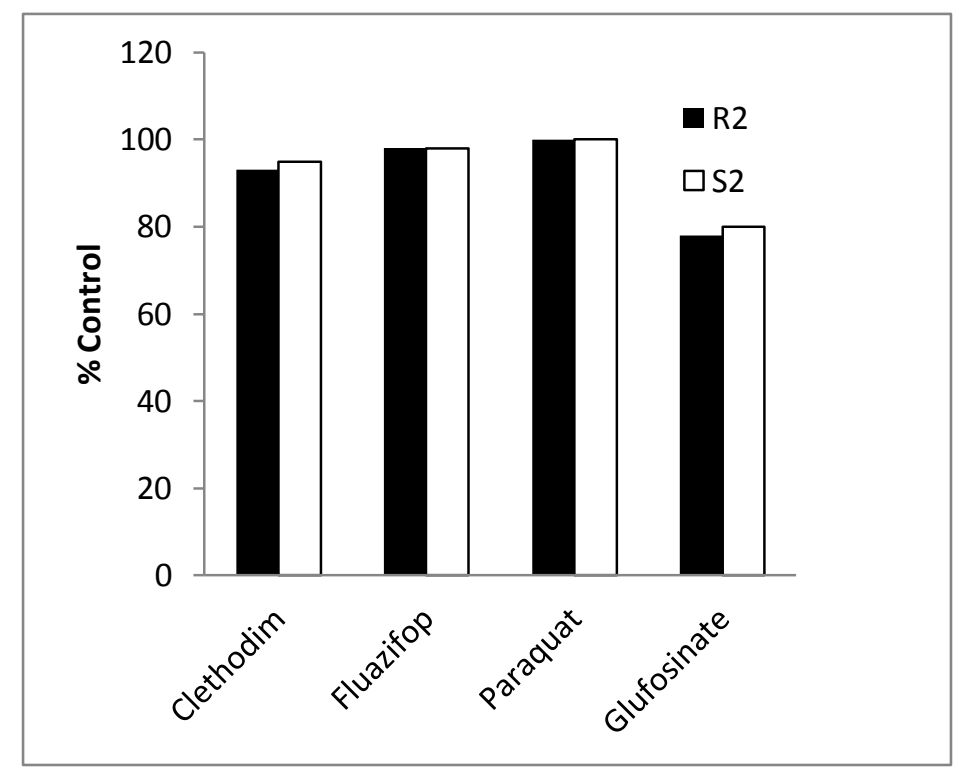

\section{Experimental}

\subsection{Plant Materials}

Goosegrass seed was collected at maturity from a soybean field located in Washington County, Mississippi, from plants surviving three $1.1 \mathrm{~kg}$ ae ha ${ }^{-1}$ applications of glyphosate. Seeds were also collected from goosegrass plants growing in neighboring fields, where glyphosate had been used, and from several other central and eastern US locations, where glyphosate had not been used. Seed from the USDA-ARS campus, Stoneville, MS, served as a susceptible check.

\subsection{Plant Culture}

Seeds were planted $0.5 \mathrm{~cm}$ deep in commercial potting mix (Redi-earth Plug and Seedling mix, SUN GRO Horticulture Distribution Inc., Bellevue, WA, USA) in $9 \times 9 \times 9 \mathrm{~cm}$ pots. Plants were placed in a greenhouse maintained at $28 / 22{ }^{\circ} \mathrm{C}$ day/night temperatures without supplemental light. When seedlings were $1 \mathrm{~cm}$ in height, they were transplanted into individual pots. Plants were irrigated once a day and fertilized once, 5 wk after planting, with a commercial fertilizer. 


\subsection{Glyphosate Dose-Response Experiments}

Dose-response experiments were conducted to establish a level of resistance to glyphosate. Glyphosate (Roundup Weathermax ${ }^{\circledR}$, Monsanto Company, St. Louis, MO, USA) was applied to test plants at the 6-leaf stage (height $7 \mathrm{~cm}$ ) using a compressed air cabinet track sprayer (Allen Machine Works, Midland, MI, USA) equipped with a flat fan nozzle (8002E) delivering 187 liter ha $^{-1}$ at $210 \mathrm{kPa}$. Seedlings were treated with the isopropylamine salt of glyphosate at rates of $0,0.1,0.2,0.4$, $0.6,0.8,1.7$ and $3.4 \mathrm{~kg} \mathrm{ha}^{-1}$. Spray solutions included $0.25 \%$ (by Volume) Induce ${ }^{\circledR}$ (Helena Chemical Company, Collierville, TN, USA) nonionic surfactant. Controls received a treatment solution minus the herbicide (i.e., adjuvant only). Experiments were performed twice and had 8 replications per treatment.

Individual plants that survived an application of $0.84 \mathrm{~kg} \mathrm{ha}^{-1}$ were grown to maturity, and seed heads from each plant were harvested and kept separate. These individuals were considered to be accessions, and each accession was given a GG\#\# designation. Three resistant accessions were chosen for further testing and designated GG14, GG16 and GG19. One accession from a sensitive population was designated GG15. Seedlings were established as previously described from these accessions.

Dose-response experiments to establish a $\mathrm{GR}_{50}$ for glyphosate were conducted using a completely randomized design with eight replications per treatment, and the experiment was repeated. Seedlings were established, as previously described, from GG15, GG14, GG16 and GG19. Glyphosate at rates of $0,0.2,0.4,0.6,0.8,1.3,1.7,2.5$ and $3.4 \mathrm{~kg} \mathrm{ha}^{-1}$ was applied to seedlings $15 \mathrm{~cm}$ in height, as previously described. At two weeks after treatment (WAT), plants were removed from the pots and the roots were discarded. The shoots were placed in paper bags, dried at $40{ }^{\circ} \mathrm{C}$ for 1 week, and dry weights were recorded.

\subsection{Leaf Disk Assay}

The shikimate accumulation microtiter plate assay [16] was used for shikimate determination with modifications in plate size and disk number to improve performance. Plants were grown as described above in $15 \mathrm{~cm}^{2}$ pots until the fourth leaf in the whorl was $20 \mathrm{~cm}$ in length. Only leaves, that were uniformly green and free of chlorotic or necrotic leaf tips, were used. From each leaf, eleven disks, $4 \mathrm{~mm}$ in diameter, were cut, and disks were placed, one per well, in $100 \mu \mathrm{L}$ of incubation buffer in 48-well microtiter plates. This process was repeated until each well contained four disks, each from a different plant of the same accession. The eleven wells contained incubation buffer and glyphosate potassium salt at concentrations of $0,0.5,1,5,10,50,100,500,1000,2000$ and $5000 \mu \mathrm{M}$. There were four replicates of each treatment, and the experiment was repeated.

\subsection{DNA Extraction}

Genomic DNA was extracted from newly emerged leaves. Tissues were sliced into $1 \mathrm{~mm}$ wide sections, and 20 to $100 \mathrm{mg}$ of tissue were homogenized with a fitted pestle in a microfuge tube containing 300-400 $\mu \mathrm{L}$ DNA extraction buffer pre-warmed to $65{ }^{\circ} \mathrm{C}$. The extraction buffer was prepared as described by Paterson et al. [17]. After incubation at $65{ }^{\circ} \mathrm{C}$ for one hour, debris was removed by centrifugation for $4 \mathrm{~min}$ at $13,400 \mathrm{rpm}$, and $266 \mu \mathrm{L}$ of the supernatant was transferred to a 
fresh tube. A DNEasy Plant mini-kit (Qiagen Sciences, MD, USA) was used for the remainder of the procedure, beginning with step 13 . DNA quantity and quality was determined by $\mathrm{A}_{260} / \mathrm{A}_{280}$ ratios and gel electrophoresis.

\subsection{Sequencing of EPSPS}

Primers were designed and designated AW1 through AW12 (Table 5) to amplify six overlapping 500-600 bp fragments of the epsps gene based on the sequence from Malaysian goosegrass.

Table 5. Primers used in PCR amplification of epsps. The binding site of each primer, relative to the Malaysian sequence (AY157642), is provided in parentheses.

\begin{tabular}{clc}
\hline Primer Name & Direction & Sequence $\left(\mathbf{5}^{\prime} \rightarrow \mathbf{3}^{\prime}\right)$ \\
\hline AW1 & Forward & GCGGAGGAGGTGGTGCT $(7-23)$ \\
AW2 & Reverse & GCGGCTGCTTCTTATCTTGG $(590-571)$ \\
AW3 & Forward & GTCGAGGTGGAGCGTGCA $(537-544)$ \\
AW4 & Reverse & CACTCCATCAAGCACATA $(1016-1033)$ \\
AW5 & Forward & CGTGACTTATCGTGCATC (982-999) \\
AW6 & Reverse & GATTTCAATCTCCACATC $(1526-1543)$ \\
AW7 & Forward & GCCTTGCTGATGGCTGC $(1493-1509)$ \\
AW8 & Reverse & GACCTGGTAAGTTTGAAC $(2076-2093)$ \\
AW9 & Forward & CTTGATGTGAACCCGCTC $(1987-2004)$ \\
AW10 & Reverse & GCAAGAGTCATGGCGACATCG (2566-2586) \\
AW11 & Forward & CACAACGTGAGCCATTTG $(2505-2519)$ \\
AW12 & Reverse & GTTCTTGACGAAAGTGCTC (3094-3112) \\
\hline
\end{tabular}

The template for the reactions was genomic DNA extracted from GG14, GG15, GG16 and GG19. Polymerase chain reactions (PCR) were performed using a TAKARA kit (Fisher Scientific, GA, USA) as follows: $\sim 50 \mathrm{ng}$ genomic DNA, $200 \mathrm{nM}$ primers, $2.5 \mathrm{mM} \mathrm{MgCl}_{2}, 400 \mu \mathrm{M} \mathrm{dNTPs}, 1 \times$ buffer, 2.5 units polymerase and $\mathrm{H}_{2} \mathrm{O}$ to $50 \mu \mathrm{L}$. Cycle conditions for reactions containing primer pairs, AW1 $\times$ AW4, AW7 $\times$ AW8, AW9 $\times$ AW10 and AW11 $\times$ AW12, were as follows: $94{ }^{\circ} \mathrm{C}$ for $1 \mathrm{~min}, 30$ cycles of $94{ }^{\circ} \mathrm{C}$ for $30 \mathrm{~s}, 55{ }^{\circ} \mathrm{C}$ for $30 \mathrm{~s}, 72{ }^{\circ} \mathrm{C}$ for $1 \mathrm{~min}, 72{ }^{\circ} \mathrm{C}$ for $5 \mathrm{~min}$ and a $4{ }^{\circ} \mathrm{C}$ hold. The annealing temperature was raised to $58{ }^{\circ} \mathrm{C}$ for reactions containing primer pairs AW1 $\times$ AW2, AW3 $\times$ AW4 and AW7 $\times$ AW10. For reactions containing primer pairs AW5 $\times$ AW8 and AW5 $\times$ AW6, the annealing temperature was lowered to $52{ }^{\circ} \mathrm{C}$. For difficult reactions, the desired fragment was amplified from a larger PCR product (i.e., AW1 $\times$ AW2 from AW1 $\times$ AW4). Following PCR, the fragments were analyzed on $1 \%$ agarose $1 \times$ TAE $(0.02 \mathrm{M}$ glacial acetic acid, $2 \mathrm{mM}$ EDTA and $40 \mathrm{mM}$ Tris base $)$ gels, stained with ethidium bromide and gel purified using the GenElute ${ }^{\mathrm{TM}}$ gel extraction kit (Sigma Aldrich, MO, USA). The concentration and quality of purified DNA fragments were assessed by $\mathrm{A}_{260} / \mathrm{A}_{280}$ ratios and gel electrophoresis.

Gel extracted PCR products were ligated into the $\mathrm{pCR}^{\circledR} 2.1$ vector using a TA cloning kit (Invitrogen, CA, USA). Ligation reactions contained: $25 \mathrm{ng}$ vector, $7 \mathrm{ng}$ insert DNA, $1 \times$ ligase buffer, 4 units of ligase and water to $10 \mu \mathrm{L}$. The reactions were incubated at $14{ }^{\circ} \mathrm{C}$ overnight, and then, the plasmids were transformed into TOP10 chemically competent cells (Invitrogen, CA, USA). TOP10 cells were prepared according to the chemically competent cell protocol [18]. Clones were screened by 
PCR amplification of the insert DNA. Positive clones were grown in LB media (1\% tryptone, $0.5 \%$ yeast extract, $0.5 \% \mathrm{NaCl}$ ) with $50 \mu \mathrm{g} / \mathrm{mL}$ ampicillin overnight at $37{ }^{\circ} \mathrm{C}$ with shaking. These clones were stored as glycerol stocks at $-80{ }^{\circ} \mathrm{C}$ and contained $800 \mu \mathrm{L}$ of cell culture added to $200 \mu \mathrm{L}$ of $80 \%$ glycerol. Three clones were selected for sequencing for each fragment (72 clones total). In preparation for sequencing, $10 \mu \mathrm{L}$ of each culture was diluted in $500 \mu \mathrm{L}$ of $\mathrm{LB}$ media containing $50 \mu \mathrm{g} / \mathrm{mL}$ ampicillin. Plasmid purification and sequence determination using M13 universal primers were performed by the USDA-ARS Genomics and Bioinformatics Research Unit, Stoneville, Mississippi, USA. Both DNA strands were covered in sequencing.

Sequence data were analyzed using Geneious Bioinformatics Software [19] (Biomatters LTD., Auckland, New Zealand). Vector sequences were removed, and sequences for each genotype were assembled. Nucleotide and protein alignments were compared to the glyphosate-resistant and -sensitive goosegrass from Malaysia (AY157642 and AY157643).

\subsection{SNP Assay}

The SNP (genotyping) assay was based on propriety TaqMan ${ }^{\circledR}$ Probe Gene Expression Analysis and real-time PCR procedures, for detecting sensitive or resistant alleles. Primers and probes (Table 6) for detecting differences between sensitive and resistant alleles were designed based on epsps sequences from GG15 and GG14, respectively.

Table 6. Primers and probes for single nucleotide polymorphism (SNP) assay. The binding site of each primer, relative to the Malaysian sequence (AY157642), is provided in parentheses.

\begin{tabular}{cc}
\hline Primer $/$ Probe & Sequence $\left(\mathbf{5}^{\prime} \rightarrow \mathbf{3}^{\prime}\right)$ \\
\hline Forward Primer & GTGCAGCTCTTCTTGGGGAAT $(836-856)$ \\
Reverse Primer & TCCTCCAGCAGCAGTTACG $(889-907)$ \\
Sensitive Probe & ATGCGACCATTGACAG $(869-884)$ \\
Resistant Probe & CAATGCGATCATTGACAG $(867-884)$ \\
\hline
\end{tabular}

Genomic DNA was isolated from goosegrass from 42 individual plants from different locations, including the original resistance site, as well as neighboring farms, local communities and other states. DNA from GG14, GG15, GG16 and GG19 were used as internal standards for the sensitive and resistant alleles. The SNP assay was performed in $25 \mu \mathrm{L}$ reactions containing $12.5 \mu \mathrm{L}$ of master mix assay reagent (Life Technologies cat. No. 4371353), $75 \mathrm{ng}$ of template DNA in $11.25 \mu \mathrm{L} \mathrm{H}_{2} \mathrm{O}$ and $1.25 \mu \mathrm{L}$ of probe/primer mix ( $8 \mu \mathrm{M}$ probe and $36 \mu \mathrm{M}$ primer) per reaction. Negative controls, in which water was used in place of a template, were included to check for contamination. The cycle conditions were as follows: $60{ }^{\circ} \mathrm{C}$ for $1 \mathrm{~min}, 95{ }^{\circ} \mathrm{C}$ for $10 \mathrm{~min}, 40$ cycles of $95{ }^{\circ} \mathrm{C} 15 \mathrm{~s}$ and $60{ }^{\circ} \mathrm{C} 1 \mathrm{~min}$ and $60{ }^{\circ} \mathrm{C}$ for $1 \mathrm{~min}$. DNA from sensitive, resistant and controls containing no template DNA were amplified in duplicate. The dyes used were VIC (R) and FAM (S) (Life Technologies). The fluorescence for each probe was measured using an ABI 7500 real-time PCR instrument (Foster City, CA, USA), and data were analyzed with ABI software. Data were plotted by using the absolute fluorescence of each reporter dye probe. Results were expressed in an allelic discrimination plot of the sensitive (C319) and resistant (T319) alleles of epsps. 


\subsection{Preemergence Herbicide Study}

A previously reported procedure [20] was used to test the response of goosegrass to preemergence herbicides. Pendimethalin (Prowl $\mathrm{H}_{2} \mathrm{O}^{\circledR}$, BASF Corporation, Research Triangle Park, NC, USA) and $s$-metolachlor (Dual Magnum II ${ }^{\circledR}$, Syngenta Crop Protection, Greensboro, NC, USA) were applied at $0.07,0.14,0.28,0.56$ and $1.12 \mathrm{~kg}$ active ingredient (ai) $\mathrm{ha}^{-1}$. The herbicides were dissolved in ethanol and diluted such that $0.5 \mathrm{~mL}$ of solution would provide the appropriate dosage rate per area. A $0.5 \mathrm{~mL}$ volume of herbicide solution was added to $100 \mathrm{~g}$ of a 1:1 (v:v) soil sand mixture, an amount sufficient to cover seeds up to $0.5 \mathrm{~cm}$. When the ethanol had evaporated, the soil sand mixture was thoroughly mixed by shaking in a plastic bag and then was poured over the seed. Twenty seeds of GG15 and GG19 populations were placed in rows in $9 \times 9 \times 9 \mathrm{~cm}$ pots containing a 1:1 (v:v) mixture of Bosket silt clay loam soil (fine-loamy mixed, active, thermic Mollic Hapludalfs) and commercial potting soil. Control pots received soil mixture treated with ethanol only. Four pots were used per concentration per population, and the experiment was repeated. After application, the pots were placed in a greenhouse and subirrigated. The greenhouse was maintained at $28 / 22{ }^{\circ} \mathrm{C}$ day/night with natural illumination. Injury was scored visually 2 WAT on a scale of $0 \%$ (no control) to $100 \%$ (complete control).

\subsection{Postemergence Herbicide Study}

Clethodim $\left(0.094 \mathrm{~kg}\right.$ ai ha ${ }^{-1}$, SelectMax ${ }^{\circledR}$, Valent USA Corporation, Walnut Creek, CA, USA), fluazifop (0.125 kg ai ha ${ }^{-1}$, Fusilade ${ }^{\circledR}$ DX, Syngenta Crop Protection, Greensboro, NC, USA), paraquat $\left(0.84 \mathrm{~kg}\right.$ ai ha ${ }^{-1}$, Gramoxone Inteon ${ }^{\circledR}$, Syngenta Crop Protection) and glufosinate (Ignite ${ }^{\circledR} 280 \mathrm{SL}$, Bayer CropScience LP, Research Triangle Park, NC, USA) were applied postemergence to resistant (GG19) and sensitive (GG15) plants at 5-8 cm height and percent control recorded 3 WAT. A crop oil concentrate (COC, Agridex ${ }^{\circledR}$, Helena Chemical Company) at $1 \%(\mathrm{v} / \mathrm{v})$ was added to each of the fluazifop and paraquat treatments. Postemergence studies were conducted in a greenhouse set to a 16 h-photoperiod and $25 / 20{ }^{\circ} \mathrm{C}$ (day/night). All treatments were applied with a moving-nozzle sprayer equipped with $8002 \mathrm{E}$ nozzles delivering $140 \mathrm{~L} \mathrm{ha}^{-1}$ at $240 \mathrm{kPa}$.

\subsection{Analysis}

Differences in experimental runs were analyzed in SAS [21] using PROC GLM. PROC NLIN was used to calculate growth reduction by $50 \%\left(\mathrm{GR}_{50}\right)$ and inhibition of shikimate accumulation $\left(\mathrm{I}_{50}\right)$ estimates based on dry weight values and micrograms of shikimate [22]. Means in the postemergence study were compared with Fisher's protected LSD test at $p=0.05$.

\section{Conclusions}

A glyphosate-resistant goosegrass population from Washington County, Mississippi, USA, was determined to have a proline to serine substitution at position 106 in EPSPS. This mutation, known to confer resistance to glyphosate, had been reported in Malaysia a decade earlier. The distance between the two locations suggests the two populations evolved separately. It may be that the allele containing the amino acid substitution exists at very low levels within goosegrass populations, and the continuous use of glyphosate has selected for it. That the population has not spread and that herbicides from 
alternative chemistries were effective at controlling the resistant population suggests that any glyphosate-resistant goosegrass can be readily contained.

\section{Disclaimer and Acknowledgments}

The mention of trade names or commercial products is solely for the purpose of providing specific information and does not imply recommendation or endorsement by the United States Department of Agriculture, an equal opportunity provider and employer. The authors would like to acknowledge Michael Gafford, Kristi Jordan, and Willie Reese for technical assistance, Deborah Boykin for assistance with statistical analysis, and William Pettigrew and John Erpelding for suggestions provided during manuscript preparation.

\section{References}

1. Duke, S.O.; Powles, S.B. Glyphosate: A once-in-a-century herbicide. Pest. Manag. Sci. 2008, 64, 319-325.

2. Powles, S.B.; Preston, C. Evolved glyphosate resistance in plants: Biochemical and genetic basis of resistance. Weed Technol. 2006, 20, 282-289.

3. Lee, L.J.; Ngim, J. A first report of glyphosate-resistant goosegrass (Eleusine indica (L.) Gaertn.) in Malaysia. Pest Manag. Sci. 2000, 56, 336-339.

4. Yuan, C.I.; Hsieh, Y.C.; Chiang, M.Y. Glyphosate-resistant goosegrass (Eleusine indica) in Taiwan: Dose-response and enzyme activity. Plant Prot. Bull. 2005, 47, 143-154.

5. Kaundun, S.S.; Zelaya, I.A.; Dale, R.P.; Lycett, A.J.; Carter, P.; Sharples, K.R.; McIndoe, E. Importance of the P106S target-site mutation in conferring resistance to glyphosate in a goosegrass (Eleucine indica) population from the Philippines. Weed Sci. 2008, 56, 637-646.

6. Mueller, T.C.; Barnett, K.A.; Brosnan, J.T.; Steckel, L.E. Glyphosate-resistant goosegrass (Eleusine indica) confirmed in Tennessee. Weed Sci. 2011, 59,562-566.

7. Baerson, S.R.; Rodriguez, D.J.; Tran, M.; Feng, Y.; Biest, N.A.; Dill, G.M. Glyphosate-resistant goosegrass. Identification of a mutation in the target enzyme 5-enolpyruvylshikimate-3-phosphate synthase. Plant Physiol. 2002, 129, 1265-1275.

8. Ng, C.H.; Wickneswari, R.; Salmijah, S.; Teng, Y.T.; Ismail, B.S. Gene polymorphisms in glyphosate-resistant and-susceptible biotype of Eleusine indica from Malaysia. Weed Res. 2003, 43, 108-115.

9. Ng, C.H.; Wickneswari, R.; Salmijah, S.; Teng, Y.T.; Ismail, B.S. Glyphosate resistance in Eleusine indica (L.) Gaertn. from different origins and polymerase chain reaction amplification of specific alleles. Austral. J. Agric. Res. 2004, 55, 407-414.

10. Ng, C.H.; Wickneswari, R.; Salmijah, S.; Ismail, B.S. Inheritance of glyphosate resistance in goosegrass (Eleusine indica). Weed Sci. 2004, 52, 564-570.

11. Perez-Jones, A.; Park, K-W.; Polge, N.; Colquhoun, J.; Mallory-Smith, C.A. Investigating the mechanisms of glyphosate resistance in Lolium multiflorum. Planta 2007, 226, 395-404.

12. Gaines, T.A.; Zhang, W.; Wang, D.; Bukun, B.; Chisholm, S.T.; Shaner, D.L.; Nissen, S.J.; Patzoldt, W.L.; Tranel, P.J.; Culpepper, A.S.; et al. Gene amplification confers glyphosate resistance in Amaranthus palmeri. Proc. Natl. Acad. Sci. USA 2010, 107, 1029-1034. 
13. Lorraine-Colwill, D.F.; Powles, S.B.; Hawkes, T.R.; Hollinshead, P.H.; Warner, S.A.J.; Preston, C. Investigations into the mechanism of glyphosate resistance in Lolium rigidum. Pestic. Biochem. Physiol. 2003, 74, 62-72.

14. Wakelin, A.M.; Lorraine-Colwill, D.F.; Preston, C. Glyphosate resistance in four different population of Lolium rigidum is associated with reduced translocation of glyphosate to meristematic zones. Weed Res. 2004, 44, 453-459.

15. Ge, X.; André d' Avignon, D.; Ackerman, J.J.H.; Sammons, R.D. Rapid vacuolar sequestration: The horseweed glyphosate resistance mechanism. Pest Manag. Sci. 2010, 66, 345-348.

16. Shaner, D.L.; Nadler-Hassar, T.; Henry, W.B.; Koger, C.H. A rapid in vivo shikimate accumulation assay with excised leaf discs. Weed Sci. 2005, 53, 769-774.

17. Paterson, A.H.; Brubaker, C.L.; Wendel, J.F. A rapid method for extraction of cotton genomic DNA suitable for RFLP or PCR analysis. Plant Mol. Biol. Rep. 1993, 11, 122-127.

18. Sambrook, J.; Fritsch, E.F.; Maniatis, T. Molecular Cloning: A Laboratory Manual, 2nd ed.; Cold Spring Harbor Laboratory Press: Plainview, NY, USA, 1989; Volume 1, pp. 82-84.

19. Drummond, A.J.; Ashton, B.; Buxton, S.; Cheung, M.; Cooper, A.; Duran, C.; Field, M.; Heled, J.; Kearse, M.; Markowitz, S.; et al. Geneious, Version 5.4; Biomatters Ltd.: Auckland, New Zealand, 2011. Available online: http://www.geneious.com (accessed on 24 October 2011).

20. Pizey, J.S.; Wain, R.L. Pre-emergent herbicidal activity of some substituted amides and related compounds. J. Sci. Food Agric. 1959, 10, 577-584.

21. SAS, Version 9.1.4; SAS Institute Inc.: Cary, NC, USA, 2002.

22. Seefeldt, S.S.; Jensen, J.E.; Fuerst, E.P. Log-logistic analysis of herbicide dose-response relationships. Weed Technol. 1995, 9, 218-227.

(C) 2013 by the authors; licensee MDPI, Basel, Switzerland. This article is an open access article distributed under the terms and conditions of the Creative Commons Attribution license (http://creativecommons.org/licenses/by/3.0/) 